\title{
The Memory of Original Wholeness and Conscious Differentiation in Genesis 1:1-2:4a
}

\author{
HELEN EFTHIMIADIS-KEITH ${ }^{1}$ (UKZN)
}

\begin{abstract}
Sakkie Spangenberg has written a number of articles dealing with Gen 1-3 in terms of its place in traditional Christian dogma and the paradigm shifts he has experienced in his understanding of this text. In this article, I would like to honour Sakkie by providing a Jungian psychoanalytic interpretation of Gen 1:1-2:4a, focusing primarily on the memory of original wholeness and the conscious differentiation that are reflected in this text. I conclude that the psyche that produced this creation story had stalled at the third stage of individuation as a result of a traumatic experience which caused it to long for its erstwhile memory of original wholeness.
\end{abstract}

KEYWORDS: Genesis; paradigm; Jungian psychoanalysis; wholeness; creation.

\section{A INTRODUCTION}

Sakkie Spangenberg boasts a long list of publications on various topics from biblical interpretation to the Psalms, Qoheleth, church dogma and church reformation. ${ }^{2}$ While his work is fascinating, I find his articles on Gen 1-3 particularly intriguing because I have long wrestled with these texts and their

* Article submitted: 3/04/2017; peer-reviewed: 11/05/2017; accepted: 16/05/2017. Helen Efthimiadis-Keith, The Memory of Original Wholeness and Conscious Differentiation in Genesis 1:1-2:4a,” Old Testament Essays 30/2 (2017): 283-299, doi: http://dx.doi.org/10.17159/2312-3621/2017/v30n2a6

1 Also known as Helen Keith-Van Wyk.

2 See, e.g. Izak J. J. Spangenberg, Die Boek Prediker, Afrikaans ed. (Kaapstad: NGK Uitgewers, 1993); Izak J. J. Spangenberg, "Wat moet ons weet en wat kan ons nog glo?” NGTT 44/1\&2 (2003): 147-160; Izak J. J. Spangenberg, “The Doctrines of Original Sin and the Virgin Birth: Divine Revelation or Human Construct?” VE 30 (2009): 221-242; Izak J. J. Spangenberg, "Opstandingsverhale en Opstandingsdogma,” HTS 67 (2011), Art. \#874, 8 pages, doi: 10.4102/hts.v67i1.874; Izak J. J. Spangenberg, "Psalm 24: Reading from Right to Left and from Back to Front," OTE 24 (2011): 746-766; and Izak J. J. Spangenberg, “Kollig op Genesis 1-3: 'n Verslag van Verskuiwende Denke en Geloof,” OTE 27 (2014): 612-636.

3 Izak J. J. Spangenberg, "Can a Major Religion Change? Reading Genesis 1-3 in the Twenty-First Century," VE 28 (2007): 259-279; Spangenberg, "Kollig,” 612-636. These texts are important for Spangenberg as they are the cornerstone on which the Christian fall-redemption-judgment master narrative is based, and are often invoked in the "science and religion” discussion (Spangenberg, "Kollig," 612-613, 619-621). 
implications for the role and dignity of women and men alike. It is no secret that traditionally androcentric interpretations have used these texts to paint a damning picture of the nature of women and their role in society. Eve has been blamed for corrupting Adam and occasioning the "Fall" of humankind, labelled the "devil's gateway," 4 and has been regarded as inferior to Adam, a "mere helper" for him. As such, her flesh-and-blood sisters have often not been regarded as the bearers of God's image, ${ }^{5}$ relegated to second-order citizens, defined as temptresses, and rendered subservient to men. It is also well known that such androcentric interpretations have been challenged by various feminist scholars who have demonstrated that these texts have been misinterpreted and that they have a restorative potential for women (and men) today. For example, as Wilfong, Freedman, and Trible have shown long ago, ${ }^{6}$ "helper" is not a negative or derogatory word in the HB. It does not refer to a menial helper, an "inferior." Rather, "helper” refers to God in the majority of times, and where it does not, it refers to a powerful "superior" upon whom the one being helped can rely. ${ }^{7}$

Jungian psychology offers an important perspective that underscores the restorative potential of Gen 1-3 and gives credence to the view that these chapters have nothing to do with the "Fall" of mankind. ${ }^{8}$ Rather, they reflect the conscious awakening/differentiation of humanity ${ }^{9}$ and foreground the crucial role of the feminine archetype or anima in human individuation/maturation. ${ }^{10}$ In my salute to Sakkie, I would like to offer a Jungian psychoanalytic reading of Gen 1:1-2:4a. I am confining my analysis to the first creation story for a number of reasons:

4 Tertullian, On the Apparel of Women 1 (ANF 4: 140), online: http://www.ccel .org/ccel/schaff/anf04.iii.iii.i.i.html.

5 Tertullian, On the Apparel, online: http://www.ccel.org/ccel/schaff/anf04.iii.iii .i.i.html.

6 Marsha M. Wilfong, “Genesis 2:18-24,” Int 421 (1988): 58-63; R. David Freedman, "Woman, A Power Equal to Man," BAR 9 (1983): 56-58; and Phyllis Trible, God and the Rhetoric of Sexuality, OBT (Augsburg: Fortress Press, 1978), 80.

7 Wilfong, "Genesis 2:18-24," 59. The prepositional phrase כנגדו "does not 'raise' the status of the helper, but rather 'brings it down' to the level of the one being helped... so as to indicate the equality between them." See Helen Efthimiadis-Keith, "Genesis 2:18-24 from a Jungian and Feminist-Deconstructionist Point of View," OTE 23 (2010): 60. For similar notions, see Trible, God, 90 and Wilfong, "Genesis 2:18-24,” 59.

8 For a discussion of Gnostic, modern and psychological positions debunking "the Fall,” see D. Andrew Kille, Psychological Biblical Criticism (Minneapolis: Fortress Press, 2001), 43-46, 87-137. See also Spangenberg, “Major Religion,” 273-275.

9 Kille, Psychological, 112-113.

10 Efthimiadis-Keith, “Genesis 2:18-24,” 53, 57, and 60-61. 
(i) Quite a number of psychological analyses have been penned on Gen 2:4b$3: 24$ or sections thereof, including my own analysis of 2:18-24. ${ }^{11}$ This is not the case for 1:1-2:4a. In fact, the longest psychological interpretations of 1:1-2:4a that I have been able to source are those of Stewart ${ }^{12}$ and Edinger, ${ }^{13}$ which comprise only seven pages in total.

(ii) I have long wanted to extend my analysis of Gen 2:18-24 ${ }^{14}$ to the remaining parts of Gen 1-3; and

(iii) Analysing both creation stories will involve far more than can be contained in an article of this nature.

I begin, then, with a brief discussion of the various aspects of Jungian theory that I will be using in my analysis, after which I will apply the theory to 1:2-3:4a.

\section{B JUNGIAN THEORY}

\section{The Individuation Process}

According to Jung, human maturation (individuation) is a process that progresses from a state of unconscious identification with original wholeness, through various stages of conscious differentiation, to conscious integration with that same wholeness. This cyclical and never-ending process is usually sparked by some obstacle or crisis that a person or nation encounters.

Briefly, any individuation cycle, whether individual of collective, progresses through five stages, to various degrees, in various areas of life: ${ }^{15}$

1. Complete identification with society. Here the person is governed completely by her/his group/societal expectations and there is no distinction between herself / himself and the group. ${ }^{16}$ This stage corresponds to the initial

11 Efthimiadis-Keith, "Genesis 2:18-24.”

12 David J. Stewart, “The Emergence of Consciousness in Genesis 1-3: Jung's Depth Psychology and Theological Anthropology,” Zygon 49 (2014): 518-519.

13 Edward F. Edinger, The Bible and the Psyche: Individuation Symbolism in the Old Testament, SJPJA (Toronto: Inner City Books, 1986), 15-19.

14 Efthimiadis-Keith, "Genesis 2:18-24."

15 The five stages referred to below are adopted and largely adapted from my 2010 article (Efthimiadis-Keith, “Genesis 2:18-24,” 50-51) which is based upon Dawson's reading of the individuation process. See Terence Dawson, "Jung, Literature, and Literary Criticism,” in The Cambridge Companion to Jung, ed. Polly Young-Eisendrath and Terence Dawson (Cambridge: Cambridge University Press, 1997), 267-268. They include my current understanding of the implications of these five stages for the psychological development (individuation) of humanity as a whole, based on Jung's concept of the collective unconscious (see 2.2).

16 Dawson, “Jung, Literature,” 267. 
wholeness or "divinity" from which human beings spring, ${ }^{17}$ that is, their collective place of psychological origin.

2. Separation from the other is a tediously long and typically painful process in which a person begins to explore and develop "his or her identity, usually by way of a dialectic with different facets of the 'other." "18 At a more complex level, this stage represents humanity's conscious separation from the original wholeness, which is crucial to the conscious differentiation of humankind, namely, to attaining a higher state of consciousness.

3. Differentiation of moral properties. This is a crucial step in the individuation cycle, where a person's shadow comes to the fore, demanding conscious integration. The person consequently tries to ascertain and establish her/his own moral or ethical code by "testing the collective morality" of one's society. ${ }^{19}$ This step is pivotal, acting as a fulcrum between the two preceding steps that require increasing conscious differentiation and the following two that require greater conscious integration. At a universal level, humanity encounters its collective shadow and begins to differentiate its own moral properties from those of the original wholeness.

4. Realisation of social reality and individual consciousness. Here the person realises that the $m a n a^{20}$ with which s/he has imbued "collective norms and expectations within which one lives are of [her/his] own making." 21 As a result, this projection is withdrawn and the person sees the world as it is. Even though the person is liberated to become "the specific human being that she or he is,"22 some form of alienation is experienced. Having been divested of its mana, the world can seem "utterly devoid of either certainty or meaning and such a perception very quickly leads to feelings of alienation." 23 In turn, the alienation necessitates the final stage. ${ }^{24}$ Stage 4 speaks to humanity's conscious awakening to its alienation from its original wholeness and "divinity."

5. Individual identity / self-realisation. At this stage, a person begins to question (consciously) her/his innate tendencies, particularly those that she / he is not aware of but which are revealed through dream analysis and conscious

17 John P. Dourley, "Memory and Emergence: Jung and the Mystical Anamnesis of the Nothing," in Barcelona 2004 - Edges of Experience: Memory and Emergence: Proceedings of the 16th International Congress for Analytical Psychology, ed. Lyn Cowan (Einsiedeln, Switzerland: Daimon Verlag, 2006), 744-746.

18 Dawson, “Jung, Literature,” 267.

19 Dawson, “Jung, Literature,” 267.

20 Mana may loosely be translated as "aura," "authority,” and "power.”

21 Dawson, “Jung, Literature,” 267.

22 Dawson, “Jung, Literature,” 267.

23 Dawson, “Jung, Literature,” 267.

24 Dawson, “Jung, Literature,” 267. 
fantasies. ${ }^{25}$ "The end ... is to know oneself not as a rebel or outsider, but as the specific human being that one is within one's own society." 26 With this, the process comes full circle: the person is re-integrated with society, the crucial distinction between Stage 5 and Stage 1 being that she/he is now fully conscious "of her/his own identity (nature, function, limitations)." 27 This stage refers to humanity's conscious re-integration with the whole, such as experienced in various mystical encounters with the divine.

\section{The Personal and Collective Unconscious Psyche}

According to Jung, a person's unconscious psyche has a personal and a collective (impersonal) component. ${ }^{28}$ The personal unconscious consists of forgotten and repressed aspects of each person's existence, while the collective unconscious underlies the consciousness of every human being from time immemorial. $^{29}$ As such, the collective unconscious contains powerful archetypes and instincts that govern everyone's course of life. The contents of both the personal and impersonal unconscious have a tremendous (emotional) effect on the individual and the society in which she/he lives. If not consciously integrated when they cross the threshold of consciousness, they may bring about maladies, maladaptive behaviours, psychoses and a will to power that destroys people, families, and nations alike. ${ }^{30}$

\section{The Shadow, the Anima and the Animus}

The three most powerful archetypes that emerge during the individuation process are the shadow, the anima, and the animus. ${ }^{31}$ The shadow essentially contains everything that a person cannot accept about herself / himself and her / his life experience. ${ }^{32}$ It is one's dark side, so to speak, while the anima and animus are the contra sexual soul images of a man and a woman, respectively. ${ }^{33}$ While these archetypes may be encountered at any stage of the individuation cycle, the shadow must be integrated at stage 3 - the differentiation of moral

25 Dawson, “Jung, Literature,” 267.

26 Dawson, “Jung, Literature,” 267 (italics mine).

27 Dawson, “Jung, Literature,” 267.

28 Carl G. Jung, Two Essays on Analytical Psychology, 2nd, rev. augmented ed., CWCGJ 7, trans. R. F. C. Hull (London: Routledge \& Kegan Paul, 1966), 52-53.

29 Carl G. Jung, Two Essays on Analytical Psychology, trans. R. F. C. Hull (New York: Meridian Books, 1956), 109.

30 Jung, Two Essays (1956), 35.

31 Carl G. Jung, Aion: Researches into the Phenomenology of the Self, CWCGJ 9/2, 2nd ed., trans. R. F. C. Hull (London: Routledge \& Kegan Paul, 1959), 8.

32 Jung, Two Essays (1956), 63-64.

33 Eugene Monick, Castration and Male Rage: The Phallic Wound (Toronto: Inner City Books, 1991), 34 and 78-79. 
properties, and the integration of the anima / animus is the sine qua non of the final stage - individual identity or self-realisation. ${ }^{34}$

\section{The Self and the Ego}

The Self is the overarching principle or consciousness guiding the psyche. ${ }^{35}$ While the Ego is the centre of consciousness, the Self is the centre of the unconscious psyche. ${ }^{36}$ Even so, the Self simultaneously governs both the conscious and unconscious psyches of human beings. The Self represents the original wholeness from which each person unconsciously stems and the wholeness to which she/he must return at a conscious level. As such, it presides over the individuation process, being both its impetus and ultimate goal. ${ }^{37}$ However, the ego is often at odds with the Self, thus impeding the withdrawal of projection and conscious integration of archetypal contents that are so crucial to a fulfilled individuation process. It is important to note that individuation takes place individually and corporately (within nations). As such, the shadow and other archetypes play a very important role in the development of persons and nations alike.

Of all the archetypes that Jung discusses, the Self comes closest to our notion of God/divinity. ${ }^{38}$ Hence, God $^{39}$ and the Self will be used interchangeably throughout this paper.

\section{Dreams, Myths, and Interpretation}

For Jung, dreams, myths, legends and even dogmas are conscious expressions of unconscious contents. ${ }^{40}$ While dreams are of a more personal nature, stemming from the personal and collective unconscious, myths and legends are

34 Helen Efthimiadis-Keith, "Structural and Psychological Coherence in the Book of Tobit," in Construction, Coherence and Connotation: Studies on the Septuagint, Apocryphal and Cognate Literature, ed. Pierre J. Jordaan and Nicholas P. L. Allen, DCLS 34 (Berlin: Walter de Gruyter, 2016), 153.

35 Wayne G. Rollins, Jung and the Bible (Eugene, OR: Wipf \& Stock, 2013), 84-85.

36 Jung, Two Essays (1966), 192.

37 Helen Efthimiadis-Keith, The Enemy is Within: A Jungian Psychoanalytic Approach to the Book of Judith, BibInt 67 (Boston: Brill Academic Publishers, 2004), 48; Rollins, Jung and the Bible, 85.

38 "Above all, God-images mirror the Self, as an expression of the immenseness of the mystery from which we are born, the heights to which we might aspire, and the depths we may have to plumb for the Self to come into its own. At the head of the list, in Jung's perspective, is the image of Christ, whom Jung says 'exemplifies the archetype of the Self'” (Rollins, Jung and the Bible, 85).

39 Elohim and Creator will also be used interchangeably with the Self.

40 Carl G. Jung, The Archetypes and the Collective Unconscious, 2nd ed., CWCGJ 9/1, trans. R. F. C. Hull (London: Routledge \& Kegan Paul, 1968), 5; EfthimiadisKeith, Enemy is Within, 66. So too Stewart, "Emergence of Consciousness," 514. 
conscious expressions of the nation from which they stem, and perhaps of humanity as a whole, which would account for the many similarities found in myths across different cultures.

Given the dream-like nature of myths and legends, interpreting myths such as Gen 1-3 as dreams is wholly in keeping with Jungian theory. In fact, Jung often turned to the Bible in his discussion of various psychological phenomena, ${ }^{41}$ and regarded biblical statements as "utterances of the soul" that point to "realities that transcend consciousness." 42 Indeed, as Edinger states, the $\mathrm{HB}$ is "an exceedingly rich compendium of images representing encounters with the nominosum [Edinger's italics] ... a grand treasury of individuation symbolism [my italics]."43

\section{Creation Stories and Individuation}

From a Jungian psychological perspective, creation stories are "simultaneously myths about the origin and emergence of human consciousness," 44 as myths of origin always are. Being archetypal, they form part of the bedrock of human experience that Jung called the collective unconscious. As such, they reflect humanity's individuation processes and the desires, aspirations and existential experiences of the nations/societies from which they stem.

With this in mind, I proceed to my Jungian reading of Gen 1:1-2:4a.

\section{A JUNGIAN READING OF GENESIS 1:1-2:4a}

The first creation story begins by catching Elohim in the middle of various acts of creation (1:1). ${ }^{45}$ It then proceeds to reveal the contents of the six days of creation and the seventh day of rest.

41 As Kille states, “Jung's writings are replete with direct and indirect references to biblical texts, allusions to biblical personages, places, symbols, and biblical phrases and concepts. Ten pages of the general index to Jung's Collected Works are devoted to biblical citations alone, not including additional allusions to biblical persons, stories, symbols, and theology” (Kille, Psychological, 81). For a thorough exposition of Jungian psychology as related to the Bible, see Rollins, Jung and the Bible.

42 Carl G. Jung, Answer to Job, trans. R. F. C. Hull (Princeton: Princeton University Press, 2010), xvi.

43 Edinger, Bible and the Psyche, 12.

44 Stewart, "Emergence of Consciousness," 509. See also Dennis G. Shulman, The Genius of Genesis: A Psychoanalyst and Rabbi Examines the First Book of the Bible (Lincoln: iUniverse, 2003), Kindle edition, chapter 2: "Just as in creation, we see the mind of God ... in the creation stories, ancient and modern, biblical and pagan, do we discover the mind of man.”

45 Shulman, Genius of Genesis, comes to this conclusion by studying the first word in Gen 1:1, namely בראשית. Shulman translates this phrase as "in the beginning of" (his italics) and states: "With 'in the beginning of,' the first verse of the Torah catches 
The earth's pre-creation rawness (it was formless and void) ${ }^{46}$ and the darkness that covered the face of the deep (1:2) are symbols of the murky reaches of the collective unconscious. However, this rawness and darkness need not be interpreted negatively, as the unconscious unfortunately often is. Rather, they are psychologically and textually a necessary precondition to ordered creation and the perception of light, both of which are symbols of the conscious psyche: ${ }^{47}$ without disorder one cannot have (or perceive) order, just as one cannot have (or recognise) light without darkness. In other words, one cannot enter consciousness unless one has first been unconscious. ${ }^{48}$

Another positive aspect - and one that is easily recognised as such, is the spirit/wind of Elohim that hovers over the face of the waters (1:2). The spirit/wind may be read as a symbol of the Self ${ }^{49}$ that hovers over humanity's as-yet-unconscious psyche, waiting for an opportunity to lead it into the first step of consciousness. ${ }^{50}$ And indeed, on a textual level, the Self gets to work immediately, creating light, the conscious spark of life (1:3), which then facilitates the first step of conscious differentiation/individuation.

The creation of light, the introduction of consciousness, is naturally followed by the division of light and dark on the first day of creation (1:4). The verb בדל (divide) signifies conscious differentiation. ${ }^{51}$ A nascent consciousness begins to emerge as the Self speaks. Light and darkness are separated and

God in the middle of God's story - not necessarily at the starting point” (Shulman, Genius of Genesis). Similarly, Robert D. Holmsted, "The Restrictive Syntax of Genesis i 1," VT 58 (2008): 56: "The traditional understanding of a reference to an 'absolute beginning' cannot be derived from the grammar of the verse. Instead, the syntax of the verse, based on well-attested features within biblical Hebrew grammar, dictates that there were potentially multiple ראשית periods of stages to God's creative work" (Holmsted, "Restrictive Syntax," 56).

46 "The tohu wa bohu and the tehom can both be considered as synonyms for the prima materia, the original not-yet created stuff which the alchemists spoke of as the increatum ... These passages [(quotations from Paracelsus)] can be read as a description of the unconscious in its aspect of potentiality" (Edinger, Bible and the Psyche, 18; Edinger's italics).

47 Stewart, following Neumann, similarly interprets light as rising consciousness (Stewart, "Emergence of Consciousness," 518).

48 Edinger, Bible and the Psyche, 19: “... every increase in consciousness (light) derives from a creative encounter with darkness, the abyss, chaos.”

49 Jeff Howlin, “The Wind," Nature and Soul: Musings of a Jungian Psychologist, http://www.santacruzpsychologist.com/blog/2013/the-wind/.

50 For Edinger, Bible and the Psyche, 19: "It is the creative encounter between spirit and undifferentiated substance that sets off the creation... This image pictures the elemental foundation ... of the psyche occurring at a pre-ego phase of development.” This, too, is a valid interpretation.

51 As indicated in section B.1., consciousness develops by splitting / differentiating / "dividing" from the unconscious psyche. 
named "day" and "night” (1:5). The act of naming, along with the following elements, seals the movement towards Stage 2 of the individuation cycle, marking it as complete: a) "God said ... and it happened"52 [1:3]; b) "God saw that it was good" [1:4]; c) "the evening and the morning were day one" [1:6]. ${ }^{53}$ The statement of divine approval (1:4) affirms the necessity of this separation/conscious differentiation.

The next four acts of creation are similarly marked by a) divine speech and the production of what this speech intended, b) division, c) naming, d) divine approval, ${ }^{54}$ and e) the formulaic phrase "it was evening then morning, Day X / the Xth Day”:

Day 2 sees the creation of the barrier ${ }^{55} /$ firmament in the midst of the waters and its use in separating the waters below and above it (1:6-7). The firmament may be read as the threshold between consciousness (the waters above) and the unconscious psyche (the waters below). Now that the psyche is no longer an unconscious whole, a threshold develops that will allow contents from the unconscious to seep through into consciousness, ultimately altering and transforming it. Interestingly, the creation of the barrier is the only creative act for which divine approval is not stated. In other words, the threshold between the conscious and unconscious psyche is neither good nor bad; it simply is. At the same time, the clear division between the waters above and those below signifies the onset of the second stage of individuation, separation from the other.

Stage 2 continues into Day 3 as the waters below are gathered to reveal the dry land (1:9). God names the dry land "earth" and the waters "sea" (1:10). Indicatively, the naming of the earth occurs before the naming of the sea in 1:10, forming a chiasm with 1:9:

Let the waters below the heavens be gathered into one place

And let the dry land appear

B

God named the dry land "earth"

B'

And the gathering of the waters "sea"

$A^{\prime}$

The chiasm and statement of divine approval following it mark the successful completion of the second stage of individuation. Furthermore, the chi-

52 Translations of biblical passages are my own unless otherwise indicated.

53 "It is telling that darkness precedes the dawn in each account. Each day begins in darkness, and ends in the dawning of a new facet of creation. This fits with the pattern of ego-consciousness gradually differentiating from the unconscious" (Stewart, “Emergence of Consciousness,” 519).

54 The creation of the barrier/firmament contains all these elements apart from the element of divine approval. For a possible reason, see the next paragraph, below.

55 Barry Bandstra, Genesis 1-11: A Handbook on the Hebrew Text, BHHB (Waco, TX: Baylor University Press, 2008), 54. 
asm encloses consciousness (the dry land) within the unconscious (the waters), mimicking the cycle of individuation as it moves from unconscious integration with the original whole (A) through various stages of conscious differentiation (B-B') to conscious integration with that original totality (A').

Stage 2 being completed, consciousness begins to produce fruit as God calls seed-bearing plants and fruit-bearing trees into being on the same day (Day 3; 1:11-12). The series of tautologies used in 1:11-12 תדשא ... דשא and underscores the self-propagating nature of the plants. Similarly, the fruit trees bear the seeds for their propagation in themselves, and make (עשהה) fruit according to their kind (1:12). For the first time in this narrative, עשהה is used for the activity of a part of God's creation and not for the Creator Self (God made [עשה] the barrier): a creation of God produces on its own once it has been called into being. The self-propagating nature of the plants and fruit trees points to humanity's innate potential for individuation.

By nature, most plants and trees sprout from the earth/dry land. ${ }^{56}$ Even so, their roots typically lie below the earth. The roots that feed plants and trees point to the necessity of drawing from the unconscious psyche and consciously developing/integrating unconscious content. More specifically, given that the earth also symbolizes the feminine principle/anima, this passage points to the necessity of consciously drawing upon the feminine principle for successful individuation, and drawing on her at an early stage of the individuation process. In other words, it points to the fact that it is crucial for one to begin consciously integrating the feminine, even before the union of the feminine and masculine principles in Stage 5 (perhaps so as to facilitate that union).

For the second time on Day 3, God endorses his creation: God saw that it was good. The firm separation of the waters and dry land $(1: 10)$ - the emergence of a firm consciousness - and the development of this consciousness by drawing on unconscious elements, particularly the feminine elements, are both "good"; they lead to higher levels of conscious differentiation and bring one closer to the conscious integration of the anima in the coniunctio (Stage 5).

God creates the sun and moon on Day 4 (1:14-19). God calls them into being, makes (עשהה) them, and sets them in the newly created sky. As intimated by the text, the sun and moon represent ordering principles: the traditionally "masculine" sun regulates the day while the traditionally "feminine" moon regulates the night. ${ }^{57}$ Moreover, these celestial bodies function as "signs" that

56 Note that God does not "make" the plants and trees as he had "made" the firmament (Day 2) and then the sun and moon (Day 3). Rather, "the earth produced" them.

57 The day and the sun are traditionally symbols for masculinity and consciousness, whereas the night and the moon are traditionally symbols of femininity and the unconscious psyche. 
together mark the passing of seasons, days, and years. In other words, they order or regulate the very rhythms of life. Even though the one is smaller than the other, science has shown that both are necessary for the correct functioning of the world. Indeed, as the text indicates, they both bring light to the earth. The same is true on a psychological plane: masculine and feminine ordering principles are equally necessary for successful conscious differentiation, for successful human development and maturation.

The importance of these lights, of consciously integrating the masculine and feminine principles, is underscored by the repeated statements of their regulatory functions as indicated by these verbs in 1:14-16: to divide, to be signs, to be lights, to give light; to rule, to rule, to give light, to rule, to divide. Furthermore, their ordering functions reflect part of the third stage of individuation, i.e. the differentiation of moral properties in which a person differentiates (divides) her/his own moral properties and 'orders' them, sometimes in opposition to those of her/his group or parental home. Even so, there is no indication of shadow assimilation, which is crucial to Stage 3.

Day 5 begins with another set of tautological expressions: "let the waters teem with teeming living creatures, and let flying creatures [birds] fly ${ }^{58}$ over the earth against the face of the heavens” (1:20). With that, God proceeds to create the very first animate beings. The two categories mentioned in 1:20, i.e. the living and flying creatures, are expanded into multiple creatures in 1:21 "the big sea creatures, every moving living creature with which the water teemed - each after its own kind, every winged bird after its kind” (1:21). The stage had been set (ordered) on Day 4 for animate life to be created, to live and to multiply, and now it has. Moreover, God blesses his first animate creations to the end of even greater multiplication, as shown by the four imperatives in 1:22: "Be fruitful, and multiply, and fill the waters in the seas, and let fowl multiply in the earth.” It is as if Day 5 ushers in a sudden, intensified surge of creation and multiplication. Psychologically, this surge represents a substantial release of libido, a general psychic energy ${ }^{59}$ that will take the individuation process further, moving it from Stage 3 to Stage 4. The movement towards a higher level of consciousness is also intimated by a number of "firsts" on Day 5: the creation of the sea creatures and the birds marks the first time in 1:1-2:4a that the verb "create" has been used of God's creative activity since the introductory verse (1:1). It is also the first time that God has addressed his creation

58 "Birds" and "fly" come from the same Hebrew root, עוף.

59 In contrast to Freud, for whom libido was primarily instinctual and sexual, Jung saw libido as "a more general psychic energy, comparable to physical energy, which could appear in many forms, sometimes in sexuality, to be sure, but also in the work of art, politics, religion, myth, fantasy, and dream, and could effect creative and constructive achievements in the individual as well as blindly instinctual forms of behavior" (Rollins, Jung and the Bible, 26-27). 
directly, and the first time that God has actively blessed his creation. These factors, combined with that fact that animate life is being created for the first time, suggest that the libidinal surge is positive, geared towards life and its promulgation rather than death, and that a higher stage of consciousness will be reached. Indeed, there is a blessing of both aspects of the psyche: the unconscious psyche as symbolised by the water and its creatures, and the conscious psyche as attested by the birds and the sky. Both are teeming with life and their potential to continue teeming with life is set into motion through God's blessing. Surprisingly, however, there is no evidence of the psyche accessing the fourth stage of individuation on Day 5.

The creation of animate life continues on Day 6, this time with the creation of land creatures: "Let the earth bring forth living creatures according to their kind: livestock, creeping/moving things, and the beasts of the earth according to their kind” (1:24). First, God calls the land creatures into being, and then makes them (1:25). Curiously, no blessing accompanies this part of God's animate creation. The lack of blessing signifies a drop in libidinal power, meaning that the potential of accessing the fourth stage of consciousness has possibly been lost. Even so, the oft-repeated statement of divine approval remains (1:26), signifying that all is not lost, growth and development can still take place.

The possibility of further development may also be seen in the somewhat chiastic relationship of 1:24 and 1:25:

\section{$1: 24$}

Let the earth produce living A creatures

Livestock

Creeping things

Beasts of the earth

\section{$1: 25$}

A' And God made

D' The beasts of the earth

C B' Livestock

D C' Creeping things

While the chiastic aspects of this relationship (B-D - D'-B') show that this part of the creation is complete, these verses leave room for further animate creation in that the chiasm is not perfect: B-C-D in 1:24 should be D'-C'-B' in 1:25 for a perfect chiasm.

The anticipation of further animate creation is satisfied immediately, with the creation of humankind:

And God said, let us make mankind in our own image, according to our likeness and let them rule over the fish in the sea, the birds in the sky, the beasts, the whole earth and over every moving/creeping thing that moves/creeps over the earth (1:26). 
Once again, God speaks the creature into being and then proceeds to create it, as he did with the rest of creation (except for the light and the vegetation).

The creation of mankind is presented in two interlinked pairs of parallel phrases, $\mathrm{A}-\mathrm{B}-\mathrm{C}=\mathrm{A} 1-\mathrm{B} 1-\mathrm{C} 1$ and $\mathrm{C} 2-\mathrm{A} 2-\mathrm{B} 2=\mathrm{C} 3-\mathrm{A} 3-\mathrm{B} 3$ as indicated below:

Let us make mankind in our own image, according to our likeness

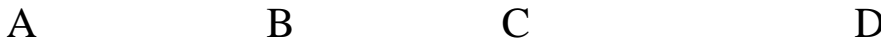

God created mankind in his image

$\begin{array}{lll}\text { A1 } & \text { B1 } & \text { C1 }\end{array}$

$\begin{array}{lll}\text { In the image of God } & \text { he created } & \text { "him" } \\ \text { C2 } & \text { A2 } & \text { B2 } \\ \text { Male and female } & \text { he created } & \text { them } \\ \text { C3 } & \text { A3 } & \text { B3 }\end{array}$

These two sets of parallelism, which share almost identical elements, underscore the completeness of humanity, i.e. the fact that it is wholly made in God's image (A-B-C=A1-B1-C1). They also show that male and female are sub-categories or "splits" of the same human being and that each is equally the image of God (C2-A2-B2=C3-A3-B3). Psychologically, it is evident that the male and female elements have not been fully integrated yet, as they are not united: the whole is mentioned and then the split into male and female elements. This suggests that Stage 5 has not been reached, which in turn shows that Stage 4 had not been reached either.

In other words, up to this point in the narrative, humanity has successfully completed Stage 2 and partially completed Stage 3 of the conscious differentiation process. It has not yet accessed Stages 4 and 5, which means that it has not come full circle to complete its individuation process. Nevertheless, God blesses his human creatures with multiplication (as he did the sea creatures and the birds), with subduing the earth and ruling over all its creatures. Furthermore, God gives humanity every self-propagating green shrub and fruit as food. The blessing and food allotment bear witness to the potential and endowment of the human creature to individuate, while subduing the earth and its creatures alludes to the human beings' ability to subdue its base passions and individuate fully, beyond Stage 3.

God then looks at all that he has made and pronounces it "very good" (1:31). Now that the "creation of the heavens and the earth and everything in them" (2:1; NLT) has been completed, God completes (finishes or ends) the works that he has done and rests on the seventh day. The verb כלה, to complete, end, finish, occurs three times in 2:1-2 underscoring the finality of the matter: God has completed all that God has done and so comes to a rest; God does not 
even speak. ${ }^{60}$ God then blesses and sanctifies this day of his rest, according to the narrator, thus marking it as a very special day. The repetitions of "rest," "seventh day" and "the works that he had made" in 2:2-3 further emphasise the importance of Day 7 on account of God having rested from his work on it. ${ }^{61}$ The first creation story then ends with this phrase: "This is the account of the heavens and the earth when they were created” (NASB; 2:4a).

\section{GENESIS 1:1-2:4a - INTERPRETING AN INTERPRETATION}

Having completed my Jungian interpretation of Gen 1:1-2:4a, I should now like to interpret my interpretation in terms of what it may tell us about the individuation level, experiences, and desires of those who may have produced it.

The first creation story is couched in perfection / completion. It begins with a void that God fills by speaking various elements of creation into being. Each creation day (Day 1-6) forms its own self-contained unit, the structure of which may be rendered roughly along the following lines:

- God said: Let there be ... and there was / God said let X produce Y

- God made / X produced Y

- God divided / X divided between Y and Z

- God named

- God saw that it was good

- The evening and the morning: Day $\mathrm{X}$

Each creation day is framed by God's speech and the final statement "it was evening and it was morning, Day X." Indeed, the whole of creation is framed within a similar inclusio as per by 1:1 and 2:4a. These frames seal each Day and the entire story, framing it as complete.

Furthermore, the original chaos is transformed and ordered into a neat, symmetrical structure that spans the first six days of creation and ends in the Creator's rest: ${ }^{62}$

60 I am indebted to Spangenberg, "Major Religion,” 267 for this insight.

61 As Spangenberg, “Major Religion,” 269 correctly states, Gen 1:1-2:4 is structured in such a way that the emphasis falls on the seventh day, thus legitimating the Sabbath celebration.

62 This table is adapted from Spangenberg, "Major Religion," 269 by the addition of the markers A, B, C, A,' B,' C.' 
Efthimiadis-Keith, “Memory of Original,” OTE 30/2 (2017): 283-299

\begin{tabular}{llllll}
\hline & DAY & ENVIRONMENT & DAY & INHABITANT & \\
A & Day 1 & Light & Day 4 & Sun, moon \& stars & A' \\
B & Day 2 & Sky and sea & Day 5 & Birds \& fish & B' \\
C & Day 3a & Dry land & Day 6a & Animals & C' \\
& Day 3b & Vegetation & Day 6b & Humans &
\end{tabular}

\section{On the seventh day God finished the work that He had been doing}

Eight acts of creation are divided into six creation days and sealed by a seventh day of rest, with seven being the number of completion and perfection (as is well-known).

On a psychological level, it is evident that conscious differentiation has taken place, as discussed in section 3. However, this differentiation is cast within a setting of wholeness or perfection. This differentiation-in-wholeness is both prospective and retrospective. Prospectively, it signifies that the psyche can complete Stage 3 and move beyond it into the fourth and then fifth stages of individuation despite the fact that it seems to have stalled at present. At the same time, however, the psyche remembers and looks back longingly on the original wholeness, the "divinity" from which it came. This retrospection would be consistent with a psyche that is almost at the fourth stage of individuation but has regressed, for it is at the fourth stage that one experiences the greatest alienation from the whole (see 2.x.).

If creation and other myths are reflective of the psyche of the nation (or faction thereof) that produced them, what might the above analyses convey about the circumstances and the psyche that produced the first creation story? The complete orderliness of creation and the longing for wholeness reflect a psyche that is in desperate need of order and wholeness. In other words, this is a psyche that has experienced the very opposite, namely disorder, chaos, and fragmentation. It is a psyche that has lost its connection with its source ${ }^{63}$ and so longs for it retrospectively. It longs for the entrance of light, for night to turn into day; it longs to be fruitful again and produce after its kind, to be gathered up and united in the image of the Self as it was "at the beginning."

As noted in the preceding section (3.), this psyche's growth has been stultified at Stage 3. Given that the shadow element is missing in the depiction of Stage 3, this is a psyche that has encountered its shadow but has not

63 Jung often said this of Western civilization. His book, Carl G. Jung, Modern Man in Search of a Soul, RoutC, trans. W. S. Dell and Cary F. Baynes (London: Routledge, 2005), is largely dedicated to this problem and its resolution. 
managed to integrate it consciously as yet. This suggests an altercation with a shadow force to which it has lost, as often happens when humanity physically battles with the "other."

Taking the above into consideration, it is possible that the nation who produced this creation story has recently experienced a situation of great turmoil that has necessitated a differentiation of moral properties vis-à-vis the "other." Sensing the alienation inherent to Stage 4, it shrinks back from this Stage, nostalgically remembering the original wholeness - an idyllic retrospective projection - from which it came. If this creation story was indeed penned in the exilic / post-exilic era, then the circumstances of the exile would fit the psycho-dynamics referred to above.

\section{E CONCLUSION}

In this article, I have analysed the first creation story in terms of Jungian psychoanalytic categories. I showed that Gen 1:1-2:4a reflects the emergence of a nascent consciousness and its development up to the third stage of conscious differentiation/individuation. Extrapolating the results to a possible situation that may have occasioned these psychological phenomena, I postulated that the psyche producing this text would have likely been one that had recently experienced separation, war, disintegration, and a loss of connection to the Self / its source. Such a situation could well be reflected in a post-exilic appraisal of the exile: the connection to God was assumed lost on account of the deportation from the sacred land, and the nation craved to be ordered and fruitful once again, re-united under the image of its Creator-God.

\section{BIBLIOGRAPHY}

Bandstra, Barry. Genesis 1-11: A Handbook on the Hebrew Text. BHHB. Waco, TX: Baylor University Press, 2008.

Dawson, Terence. “Jung, Literature, and Literary Criticism.” Pages 255-280 in The Cambridge Companion to Jung. Edited by Polly Young-Eisendrath and Terence Dawson. Cambridge: Cambridge University Press, 1997.

Dourley, John P. "Memory and Emergence: Jung and the Mystical Anamnesis of the Nothing.” Pages 744-756 in Barcelona 2004 - Edges of Experience: Memory and Emergence: Proceedings of the 16th International Congress for Analytical Psychology. Edited by Lyn Cowan. Einsiedeln, Switzerland: Daimon Verlag, 2006.

Efthimiadis-Keith, Helen. The Enemy is Within: A Jungian Psychoanalytic Approach to the Book of Judith. BibInt 67. Boston: Brill Academic Publishers, 2004. "Genesis 2:18-24 from a Jungian and Feminist-Deconstructionist Point of View." OTE 23/1 (2010): 44-65. . "Structural and Psychological Coherence in the Book of Tobit." Pages 149-164 in Construction, Coherence and Connotation: Studies on the Septuagint, Apocryphal and Cognate Literature. DCLS 34. Edited by Pierre J. Jordaan and Nicholas P. L. Allen. Berlin: Walter de Gruyter, 2016. 
Edinger, Edward F. The Bible and the Psyche: Individuation Symbolism in the Old Testament. SJPJA. Toronto: Inner City Books, 1986.

Freedman, R. David. “Woman, A Power Equal to Man.” BAR 9 (1983): 56-58.

Holmsted, Robert D. “The Restrictive Syntax of Genesis i 1.” VT 58 (2008): 56-67.

Howlin, Jeff. “The Wind,” Nature and Soul: Musings of a Jungian Psychologist, http://www.santacruzpsychologist.com/blog/2013/the-wind/.

Jung, Carl G. Two Essays on Analytical Psychology. Meridian ed. Translated by R. F. C. Hull. New York: Meridian Books, 1956. . Two Essays on Analytical Psychology. 2nd, rev. augmented ed. CWCGJ 7. Translated by R. F. C. Hull. London: Routledge \& Kegan Paul, 1966. . The Archetypes and the Collective Unconscious. 2nd ed. CWCGJ 9/1. Translated by R. F. C. Hull. London: Routledge \& Kegan Paul, 1968. . Aion: Researches into the Phenomenology of the Self. CWCGJ 9/2. 2nd ed.

Translated by R. F. C. Hull. London: Routledge \& Kegan Paul, 1959. . Modern Man in Search of a Soul. RoutC. Translated by W. S. Dell and Cary F. Baynes. London: Routledge, 2005. . Answer to Job. (From Vol. 11 of the Collected Works of C. G. Jung). Translated by R. F. C. Hull. Princeton: Princeton University Press, 2010. Adobe DRM edition. Kille, D. Andrew. Psychological Biblical Criticism. Minneapolis: Fortress Press, 2001. Monick, Eugene. Castration and Male Rage: The Phallic Wound. Toronto: Inner City Books, 1991.

Rollins, Wayne G. Jung and the Bible. Eugene, OR: Wipf \& Stock, 2013.

Shulman, Dennis G. The Genius of Genesis: A Psychoanalyst and Rabbi Examines the First Book of the Bible. Lincoln, NE: iUniverse, Inc. 2003. Kindle Edition.

Spangenberg, Izak J. J. Die Boek Prediker. Afrikaans ed. Kaapstad: NGK Uitgewers, 1993. ."Wat moet ons weet en wat kan ons nog glo?” NGTT 44/1\&2 (2003): 147-160. . "Can a Major Religion Change? Reading Genesis 1-3 in the Twenty-First Century.” VE 28/1 (2007): 259-279. "The Doctrines of Original Sin and the Virgin Birth: Divine Revelation or Human Construct?” VE 30/1 (2009): 221-242. . “Opstandingsverhale en opstandingsdogma.” HTS 67/1 (2011). Art. \#874. 8 pages. Doi: 10.4102/hts.v67i1.874. . "Psalm 24: Reading from Right to Left and from Back to Front." OTE 24/3 (2011): 746-766. “Kollig op Genesis 1-3: 'n Verslag van Verskuiwende Denke en Geloof.” OTE 27/2 (2014): 612-636.

Stewart, David J. “The Emergence of Consciousness in Genesis 1-3: Jung's Depth Psychology and Theological Anthropology.” Zygon 49/ 2 (2014): 509-529.

Tertullian, On the Apparel of Women, Book 1. In Fathers of the Third Century: Tertullian, Part Fourth; Minucius Felix; Commodian; Origen, Parts First and Second . Edited by Philip Schaff. Vol. 4 of The Ante-Nicene Fathers. Edited by Alexander Roberts and James Donaldson. 1885-1887. 10 vols. Repr. Peabody, Mass.: Hendrickson, 1994. Online: http://www.ccel.org/ccel/schaff/anf04.iii.iii.i.i .html.

Trible, Phyllis. God and the Rhetoric of Sexuality. OBT. Augsburg: Fortress Press, 1978. Wilfong, Marsha M. “Genesis 2:18-24.” Int 421 (1988): 58-63.

Dr. Helen Efthimiadis-Keith (AKA Helen Keith-van Wyk), School of Religion, Philiosophy and Classics, UKZN. Email: helenkeithvanwyk@gmail.com. 